\title{
Twenty-six years of uneven changes in low flows due to different uses and operation of a large dam in a semiarid river
}

Vinte e seis anos de mudanças desiguais nas vazões mínimas devido a diferentes usos e operação de uma grande batragem em um rio no Semiárido

\section{Fernando Genz ${ }^{1}$ e Guilherme Camargo Lessa ${ }^{2}$}

\author{
${ }^{1}$ Pesquisador do Mestrado em Meio Ambiente, Águas e Saneamento, Universidade Federal da Bahia, BA, Brasil \\ fgenz@pq.cnpq.br
}

${ }^{2}$ Instituto de Geociências, Universidade Federal da Bahia, BA, Brasil gclessa@gmail.com

Recebido: 29/06/14 - Revisado: 16/11/14 - Aceito: 05/12/14

\begin{abstract}
Little is known about the hydrological impact of the dams in Brazil, despite the rising energy demand and untapped potential. The Paraguacu River's discharge has been greatly impacted since 1986 by a large dam built in the lower course of the river. In the 26 years of the bistory of the dam, the minimum discharges have followed different operational guidelines: 1) there was no established discharge minimum between 1987 and 1996; 2) the discharge minimum was $11 \mathrm{~m}^{3} \mathrm{~s}^{-1}$ between 1997 and 2004; and 3) bydropower generation began in 2005, when local wet season discharges were either $80 \mathrm{~m}^{3} \mathrm{~s}^{-1}$ or $160 \mathrm{~m}^{3} \mathrm{~s}^{-1}$, and dry-season pulses of $10 \mathrm{~m}^{3} \mathrm{~s}^{-1}$, which were adopted as minimum stream flow. The mean annual dam discharge between 1987 and 2012 was $17.4 \%$ less than the incoming river flow. While rare events of daily null flow exist in the historic records, bundreds of occurrences of daily null flow have been observed in the outgoing discharge since 1987. Other important hydrologic alterations (IHAs) have included: the one-day minimum, the 3-day minimum and the number of low-discharge pulses. Ecochange analysis indicates an overall discharge loss (ecodeficit) in the system. The period of dam operation has coincided with a noticeable drop in the natural river discharge, when the mean discharge was 32\% lower than in the pre-dam period (1947-1986)
\end{abstract}

Keywords: Hydrological alterations. Dam. Low discharge. Semiarid basin

\section{RESUMO}

No Brasil pouco se conhece a respeito dos impactos hidrológicos decorrentes de barragens, apesar da demanda crescente de energia e do potencial ainda inexplorado. As vazões no Rio Paraguaçu no seu baixo curso foram muito impactadas desde 1986 devido a construção de uma grande barragem. Nos 26 anos de história da barragem, as vazões minimas liberadas estiveram sob diferentes regras operacionais: 1) sem valor minimo entre 1987 e 1996; 2) vazão mínima de $11 \mathrm{~m}^{3} \mathrm{~s}^{-1}$ entre 1997 e 2004; e 3) com o início da geração bidrelétrica em 2005, para o período úmido as varõos foram de $80 \mathrm{~m}^{3} \mathrm{~s}^{-1}$ a $160 \mathrm{~m}^{3} \mathrm{~s}^{-1}$ e no período seco pulsos de $10 \mathrm{~m}^{3} \mathrm{~s}^{-1}$, estes adotados como vazão minima 'ambiental'. A vazão média liberada para jusante da barragem entre 1987 e 2012 foi 17,4\% menor que a vazão afluente ao reservatório. Enquanto nos registros históricos eram raros os eventos de descarga nula, a partir de 1987 passaram a ocorrer centenas de dias com vazão nula a jusante da barragem. Outras alterações hidrológicas importantes incluem: a vazão mínima diária, vazão mínima de 3 dias e o número de pulsos de vazões mínimas. A análise de ecomudanças indicou uma perda de vazão generalizada no sistema para jusante. O periodo de operação da barragem (1987 a 2012) coincidiu com uma notável diminuição na descarga natural do rio, quando a vazão média ficou 32\% abaixo daquela do periodo pré-barragem (1947 a 1986).

Palavras Chave: Alterações hidrológicas. Barragem. Vazões minimas. Semiárido 


\section{INTRODUÇÃO}

The impacts of large dams on river hydrology and ecosystems have been reported extensively by scientists and professional groups such as the International Commission on Large Dams (ICOLD), the International Hydropower Association, The World Commission on Dams (WCD) and the International Energy Agency. Large dams are defined by ICOLD (2011) as a dam having a height not less than 15 meters above the foundation or, if the height is between 5 and 15 meters, having a reservoir capacity of more than $3 \times 10^{6} \mathrm{~m}^{3}$. Large river dams promote low-cost electricity, navigation, flood control and a bountiful water supply, which have had a profound impact on the implementation of the present social framework and territorial occupation (COLLIER et al., 2000; REVENGA et al., 2000). In many cases, dams change the biochemical cycle in the natural riverine/estuarine system, interrupting the downstream flow of sediments and organic carbon (WCD, 2000).

From a hydrologic perspective, flood control and the production of hydroelectricity generally entail a reduction of the maximum and mean annual discharges, an increase of the daily mean and minimum discharges, and an alteration of the annual flow regime in areas with a well-defined rainy season (BRANDT, 2000). If an urban/agricultural water supply is required, not only the annual but also the daily mean discharge is reduced because water is diverted out of the system.

In line with a global trend, Brazil has invested heavily in large dams throughout the twentieth century, when 823 dams were built in accordance with the Brazilian Committee on Large Dams (2000). However, the evaluation of their hydrological impact has been limited, with the majority of the investigations focusing on alterations of the hydrologic regime that have occurred post damming in the rivers São Francisco (LUZ; GENZ, 2010; GENZ; LUZ, 2012), Tucuruí (MANYARI, 2007),Manso (Souza, 2009) and Paraná (STEVAUX et al., 2009; ROCHA, 2010). The results indicate a significant increase of the minimum daily and monthly discharges, in addition to a rise in the rates of hydrogram ascension and recession. Two exceptions to this trend are the studies by Groppo et al. (2009) and Lima et al. (2010), who examined the impact of dams used for irrigation and urban supply and reported a reduction of the maximum and minimum discharges. Souza (2009) innovated by analyzing the hydrological alterations and different proposals for environmental flows before building of the Belo Monte dam on the Xingu River.

The evaluation of hydrological impacts caused by dams and other manmade interferences on a river course has been aided extensively by the application of the IHA method (RICHTER et al., 1996). The IHA method utilizes five main groups of analyses, each group aiming at distinct hydrological aspects relative to aquatic ecosystems. Examples of IHA applications, in addition to the aforementioned Brazilian studies, are those of Richter et al. (1997) in the Roanoke River (USA), Maingi and Marsh (2002) in the Tana River (Kenya), Kiesling (2003) in the Trinity River (USA), Olden and Poff (2003) and Magilligan and Nislow (2005) at many different sites on several USA rivers, Lian et al. (2011) in the Illinois River and Mobley et al. (2012) in the Rivanna River (USA).

Hydrological impact is a very important issue to the Latin American countries because there is a rising energy demand and untapped potential (FINE; JENKINS, 2012).

This study will address the impact of the Pedra do Cavalo Dam (PCD) on the hydrological regime of the Paraguaçu River, in northeast Brazil. The dam was built between 1982 and 1985 to produce hydroelectricity, provide flood protection to downstream towns and supply water to neighboring urban centers (population $\sim 3.5$ million). Hydroelectricity production was initiated, however, only in 2005. Despite its large size, the Pedra do Cavalo dam was not included in the worldwide assessment of dam-based impacts on fluvial systems of Nillson et al. (2005) due to the relatively small mean annual flow $(<350$ $\left.\mathrm{m}^{3} \mathrm{~s}^{-1}\right)$ of the river, which, is one of the characteristic of a large semi-arid watershed.

This study aims to investigate the connection between the hydrological changes and modes of the dam's operation within its 26 years of existence and to provide background information to aid in the assessment of downstream hydrological and ecological alterations.

\section{STUDY AREA AND DATA SET}

The PCD catchment area encompasses a semi-humid climate belt in its very lower course and in the upper catchment, and a semi-arid climate with no excess of precipitation in its middle course (Figure 1). Precipitation in the semi-humid zones is out of phase, taking place between November and January in the upper river course when major river floods occur and between April and July (dry season in the upper catchment) in the lower catchment.

The PCD is $142 \mathrm{~m}$ high and stores $4.63 \times 10^{9} \mathrm{~m}^{3}$ drained from a $53,866 \mathrm{~km}^{2}$ catchment area (AMORIM, 2006) with a daily mean discharge of $93 \mathrm{~m}^{3} \mathrm{~s}^{-1}$ (1946 to 2003) (GENZ, 2006). The flow regime of the river is torrential, and a typical flood hydrogram is 7 days long. The ascending phase of the hydrogram may vary from a few cubic meters per second to hundreds or even thousands of cubic meters per second in 1 to 2 days ( $4000 \mathrm{~m}^{3} \mathrm{~s}^{-1}$ for 20 -year return period).

The dam operation is based on the river discharge, the level of the reservoir, and the measured and forecast rainfall. The discharge operates only through floodgates, as there is no releasing mechanism at the base of the dam (106 m). Between 1987 and 2004, two basic operational modes were adopted, one for the dry season and another for the flood season. In the dry season, the dam mean daily discharge would be $5 \mathrm{~m}^{3} \mathrm{~s}^{-1}$ if the river discharge were smaller than $10 \mathrm{~m}^{3} \mathrm{~s}^{-1}$; otherwise, the outgoing discharge would be $12.5 \mathrm{~m}^{3} \mathrm{~s}^{-1}$. The 'mean daily' value was obtained by alternating between $50 \mathrm{~m}^{3} \mathrm{~s}^{-1}$ and $60 \mathrm{~m}^{3} \mathrm{~s}^{-1}$ for 2 to 5 hours. Only in 1997, when environmental licensing was implemented, were the formal dry season operation guidelines finally implemented, but with a discharge minimum set at $11 \mathrm{~m}^{3} \mathrm{~s}^{-1}$.

Dam operation during the flood season was aimed at maintaining the reservoir level below the $120 \mathrm{~m}$ mark to prevent floods with a recurrence time of 30 years $\left(\sim 4510 \mathrm{~m}^{3} \mathrm{~s}^{-1}\right)$. Under 


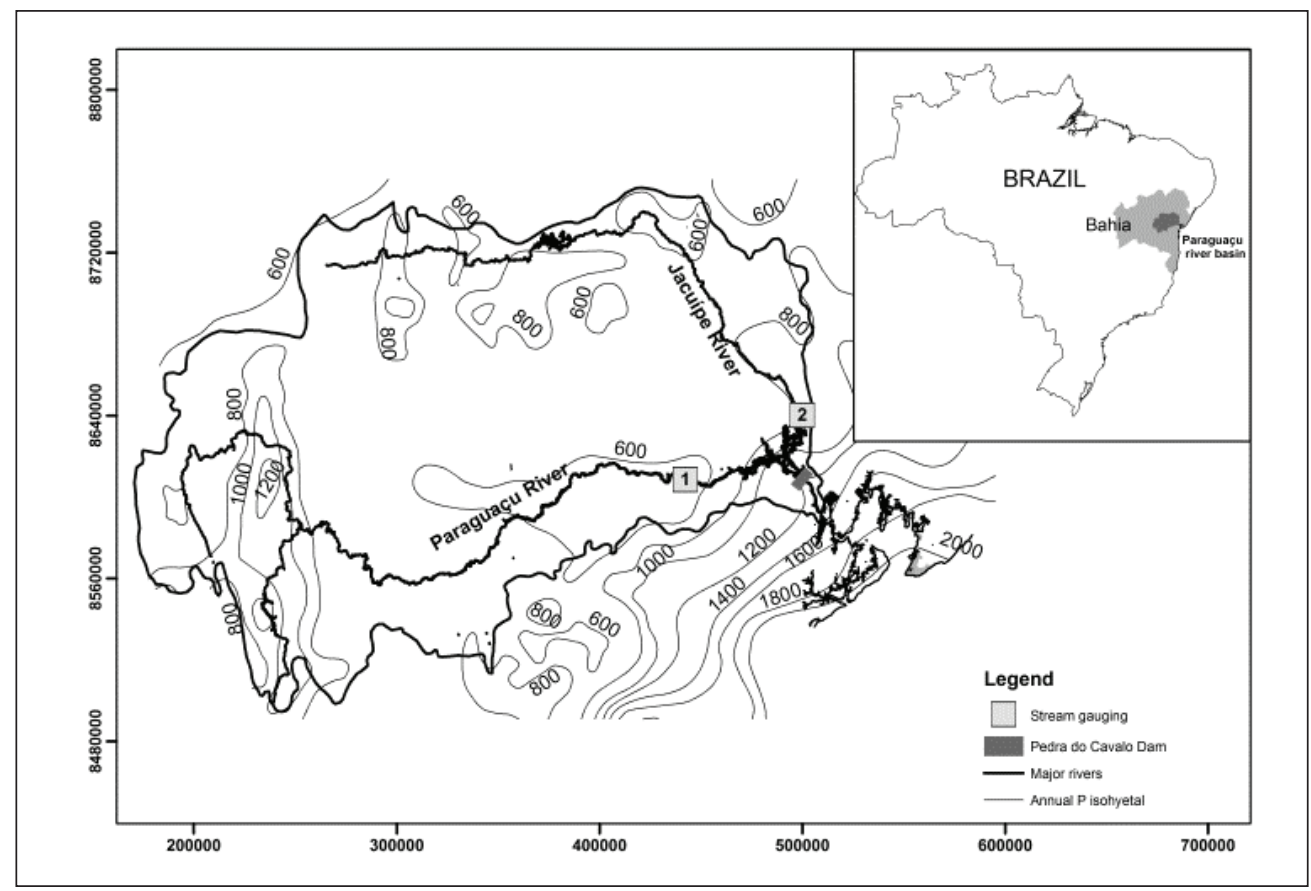

Figure 1 - Location of the dam, its catchment area and streamflow gauging stations (1-Argoim; 2-Ponte Rio Branco)

these circumstances, released discharges would be no higher than $2000 \mathrm{~m}^{3} \mathrm{~s}^{-1}$ to avoid flooding downstream towns. A discharge of $1500 \mathrm{~m}^{3} \mathrm{~s}^{-1}$ was usually released in December to lower the reservoir level to $120 \mathrm{~m}$.

Operational guidelines were modified after the hydroelectric power plant (165.3 MW) went into operation in 2005. The plant is composed of 2 turbines of $82.6 \mathrm{MW}$ each, under a maximum discharge of $80 \mathrm{~m}^{3} \mathrm{~s}^{-1}$, and is capable of yielding $700.000 \mathrm{MWh} /$ year. The reservoir level must stay between the $108 \mathrm{~m}$ mark and the $120 \mathrm{~m}$ mark, but the $114.5 \mathrm{~m}$ mark was set as a reference for year-round energy production. During the flood season, the outgoing discharge is either $80 \mathrm{~m}^{3} \mathrm{~s}^{-1}$ or $160 \mathrm{~m}^{3} \mathrm{~s}^{-1}$ through the turbines, whereas any excess is released through the gates. In the dry season, discharge pulses are liberated by one turbine to obtain a mean daily discharge of $10 \mathrm{~m}^{3} \mathrm{~s}^{-1}$, which is considered the minimum stream flow. Evaporation losses in the reservoir have been estimated as $2.7 \mathrm{~m}^{3} \mathrm{~s}^{-1}$, or $3.5 \%$ of the mean annual discharge. The average water draft for human consumption was $10.7 \mathrm{~m}^{3} \mathrm{~s}^{-1}$ between 1987 and 2003 (GENZ, 2006).

\section{Hydrologic data}

An extensive network of stream gauging stations exists in the Paraguaçu River catchment area, with the majority belonging to the National Water Agency (ANA). Two stations are central to the analysis of the discharge into the reservoir, namely, Argoim (\#51350000) and Ponte Rio Branco (\#51460000) (Table 1). These stations monitor the Paraguaçu (that accounts for $90 \%$ of the total flow) and Jacuípe Rivers immediately before they debouch into the PCD reservoir (Figure 1). River discharge is also monitored indirectly through the reservoir water level by the State Water Agency. The incoming discharge to the PCD reservoir is calculated by the sum of the Argoim and Ponte Rio
Branco station discharges.

Table 1 - General information on the stream gauging stations

\begin{tabular}{ccccc}
\hline N. & Code & Station Name & River & $\begin{array}{c}\text { Area } \\
\left(\mathrm{km}^{2}\right)\end{array}$ \\
1 & 51350000 & Argoim & Paraguaçu & 37,345 \\
2 & 51460000 & Ponte Rio Branco & Jacuípe & 10,560 \\
\hline
\end{tabular}

\section{METHODS}

\section{Interannual variability}

The analysis of interannual variability utilized techniques applied by climatic studies (e.g.PEKÁROVÁ et al., 2003), where the time series is normalized to define the anomalies. The anomaly $(\mathrm{An})$ is given by

$$
A n=(Q-Q m) / \sigma
$$

where $\mathrm{Q}=$ annual mean discharge, $\mathrm{Qm}=$ average discharge, and $\sigma=$ standard deviation.

\section{Determining hydrologic changes}

\section{The Indicators of Hydrologic Alterations (IHA)}

The IHA (RICHTER et al. 1996) is a suite of statistics developed by the US Nature Conservancy to assess the degree of hydrological alteration induced by human intervention in a fluvial system. The IHA addresses five key components of variability (magnitude, frequency, duration, timing and rate of change) that are central to sustaining biodiversity and ecosystem integrity (THARME, 2003). 
Of the 33 parameters, 17 are directed to the analysis of magnitude, duration, timing and frequency of extreme events due to the strong influence of these events on the ecosystem and geomorphology. The remaining parameters measure the central trend, both in terms of magnitude and rate of change. The IHA also highlights changes in the temporal distribution of discharges in addition to changes in the form of the hydrogram. The IHA results are used in the Range of Variability Approach (RVA) (RICHTER et al., 1997), a method designed to establish a range of variation in each of the 33 parameters. Here, we will base the RVA on the mean and one standard deviation (parametric statistics) to apply the DHRAM method (described below).

To evaluate changes, the IHA method takes into consideration a time series before and after the beginning of dam operation. In this paper, however, we will use the incoming river discharge and the outgoing dam discharge between the hydrologic years (Oct-Sep) of 1987 and 2012. This selection is justified because of the relatively short term of dam operation and the length of climate cycles (up to 30 years) that, at this point, would introduce strong biases to the analyses. An assessment of the hydrological regime in the lower reach of the São Francisco River after the implementation of hydropower plants (GENZ; LUZ, 2012) showed that dam operation has been responsible for $59 \%$ of hydrological changes, while the climate (under the driest conditions) has contributed to $41 \%$ of the total changes.

\section{Total seasonal ecochange}

Another approach to evaluate the overall hydrologic alteration was proposed by Gao et al. (2009) and is called total seasonal ecochange, the sum of all the seasonal ecodeficits and ecosurpluses within a year. The terms ecosurpluses and ecodeficits were originally introduced by Vogel et al. (2007) as non-dimensional metrics derived from the flow duration curve (FDC) of the regulated and unregulated river flow. The area falling between these curves (when plotted together) is related to the ecodeficit (when the regulated FDC is located below the unregulated FDC) or ecosurplus (when the regulated FDC is located above the unregulated FDC). Two main seasons have been defined for the Paraguaçu River discharge based on precipitation in the upper catchment: a wet season between November and March and a dry season between April and October. Ecosurpluses and ecodeficits were computed for the three different periods of dam operational rules.

\section{DHRAM Method}

Black et al. (2005) developed a method for assessing the degree of human alteration of river flow regimes relative to near-natural or reference conditions. The Dundee Hydrological Regime Alteration Method (DHRAM) utilizes the Indicators of Hydrologic Alteration, with parametric statistics, to classify the risk of damage to instream ecology using a five-class scheme compatible with the requirements of the EC Water Framework Directive. DHRAM uses daily mean flow time-series data, representing unimpacted and impacted situations for the site of interest in relation to any type of anthropogenic hydrological impact, such as impoundments, abstractions or increased flows.

DHRAM yields a score (from 0 to 30 ) based on the overall percentage of change in the IHA parameters. The higher the score, the greater the flow regime alteration and the higher the risk of damage to the ecosystem. The score enables determination of the DHRAM class, which ranges from Class 1 (unimpacted condition) to Class 5 (severely impacted condition) (Table 2). The point ranges are defined by the hydrological change thresholds used for allocation of impact points (see Black et al. 2005).

Table 2 - Definition of DHRAM classes (Black et al., 2005)

\begin{tabular}{rrl}
\hline \multicolumn{2}{l}{ Point Classification } & \\
\hline \multicolumn{1}{l}{ Class } & Points range & Description \\
\hline 1 & 0 & Unimpacted condition \\
2 & $1-4$ & Low risk of impact \\
3 & $5-10$ & Moderate risk of impact \\
4 & $11-20$ & High risk of impact \\
$5^{*}$ & $21-30$ & Severely impacted condition \\
\hline
\end{tabular}

Complementary questions:

1. The classification is dropped (down the table) by one if anthropogenic sub-daily flow fluctuations exceed 25\% of the $95 \%$ exceedance flow, and/or

2. It is provisionally dropped by one class if flow cessation occurs as a result of the anthropogenic process(es).

* Class 5 is the lowest classification that can be allocated.

\section{RESULTS}

\section{Interannual variation}

The Paraguaçu River discharges have undergone large interannual variation. The mean discharge at Argoim, which represents the bulk of the river discharge, was $80 \mathrm{~m}^{3} \mathrm{~s}^{-1}$ between 1947 and 2012, with a standard deviation of $49 \mathrm{~m}^{3} \mathrm{~s}^{-1}$ (Figure 2). Coincident with the beginning of the PCD operation, there was a noticeable drop in the river discharge. The annual mean discharge between 1947 and 1986 was $91.7 \mathrm{~m}^{3} \mathrm{~s}^{-1}, 47 \%$ higher than the annual mean of $62.6 \mathrm{~m}^{3} \mathrm{~s}^{-1}$ between 1987 and 2012. River discharge anomalies have been the highest negative in the record, with strongly negative and weakly positive anomalies

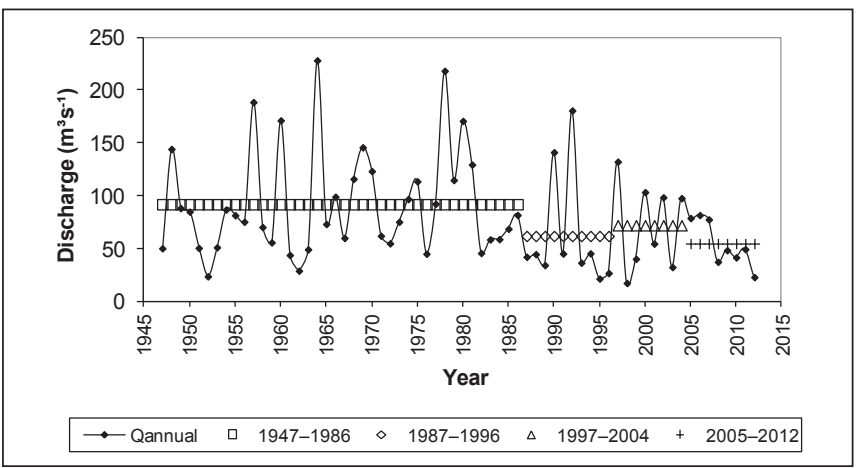

Figure 2 - Interannual variation of the mean annual river discharge anomaly (Argoim station) 
Genz e Lessa: Twenty-six years of uneven changes in low flows due to different uses and operation of a large dam in a semiarid river

prevailing since the dam was built.

Within the time of the PCD operation, 3 sub-periods must be addressed to account for different operational guidelines: i) between 1987 and 1996, when the lowest annual mean discharge was recorded $\left(61.6 \mathrm{~m}^{3} \mathrm{~s}^{-1}\right)$; ii) between 1997 and 2004 $\left(71.8 \mathrm{~m}^{3} \mathrm{~s}^{-1}\right)$; and iii) between 2005 and $2012\left(54.5 \mathrm{~m}^{3} \mathrm{~s}^{-1}\right)$ (Figure 2 and Table 3).

Table 3 - Annual mean discharges for the Paraguaçu River at Argoim station for different operational periods

\begin{tabular}{cc|cccc}
\hline & $\begin{array}{c}\text { Before } \\
\text { PCD }\end{array}$ & $\begin{array}{l}\text { After } \\
\text { PCD }\end{array}$ & & & \\
\hline & $1947-$ & $1987-$ & $1987-$ & $1997-$ & $2005-$ \\
Period & 1986 & 2012 & 1996 & 2004 & 2012 \\
Qm(m $\left.\mathrm{m}^{3} \mathrm{~s}^{-1}\right)$ & 91.7 & 62.6 & 61.6 & 71.8 & 54.5 \\
& & & & & \\
\hline
\end{tabular}

\section{Dam impact on hydrology}

Hydrologic changes associated with the PCD are initially determined on the basis of the incoming and outgoing annual mean discharges. The annual mean river discharge between 1987 and 2012 was $69.5 \mathrm{~m}^{3} \mathrm{~s}^{-1}$ (the sum of Argoin and Ponte do Rio Branco annual mean river discharges), whereas the outgoing discharge was $57.6 \mathrm{~m}^{3} \mathrm{~s}^{-1}$, which represents a reduction of 12.1 $\mathrm{m}^{3} \mathrm{~s}^{-1}$ or $17.4 \%$. Changes of the maximum and minimum annual mean discharges were reversed, with the maximum rising from $203 \mathrm{~m}^{3} \mathrm{~s}^{-1}$ (1992) to $222 \mathrm{~m}^{3} \mathrm{~s}^{-1}$ (1990) and the minimum falling from $17.5 \mathrm{~m}^{3} \mathrm{~s}^{-1}$ (1998) to $9.9 \mathrm{~m}^{3} \mathrm{~s}^{-1}$ (1987).

The IHA results highlight the effects associated with the operational guidelines on the minimum discharges. The three most important hydrologic alterations were i) the number of days with zero discharge; ii) annual minimum discharges that include the one-day minimum and the 3-day minimum; and iii) the number of low-flow pulses.

\section{Days with zero discharge}

The number of days with null discharge for the incoming flow was zero for all years, with the exception of the 1998 El Niño event. However, hundreds of occurrences of null discharge were observed in the outgoing discharge. Most of the occurrences of null outgoing daily discharge took place

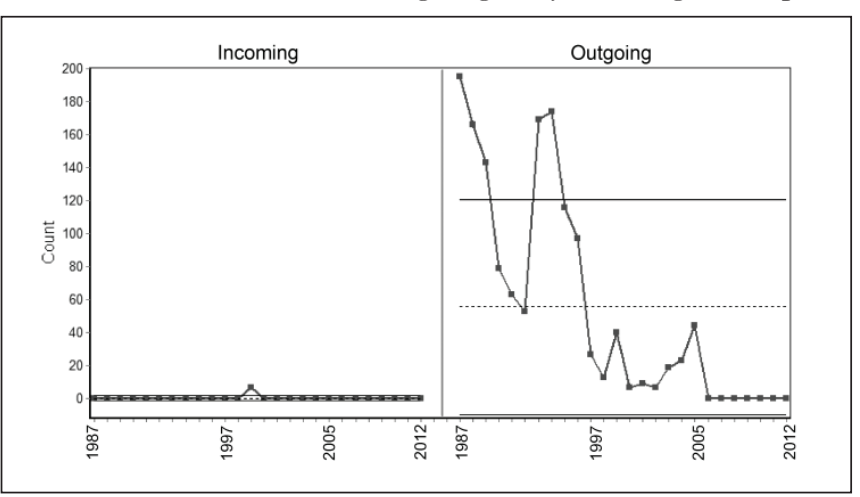

Figure 3 - Number of days between 1987 and 2012 with null discharge incoming and outgoing of the PCD between 1987 and 1996. From that point forward, null discharges diminished gradually until the power plant became operative in 2005 (Figure 3).

\section{Annual minimum discharges}

The annual minimum discharges underwent radical changes (Figure 4). The incoming annual minimum discharges for 1,3 and 7 days had a mean value around $4.5 \mathrm{~m}^{3} \mathrm{~s}^{-1}$. The outgoing 1-day minimum discharge was always zero, and even the outgoing 3- and 7-day minimum discharges had instances with null discharge. In the case of the 30-day minimum, there were 2

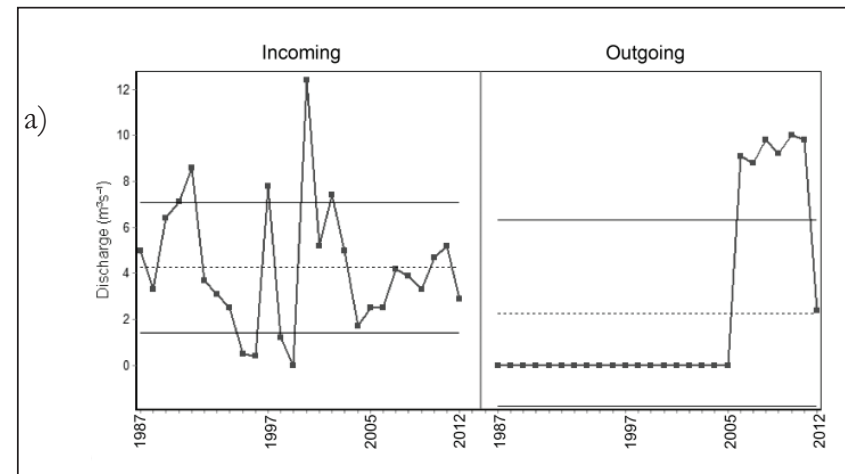

b) eixo $x$

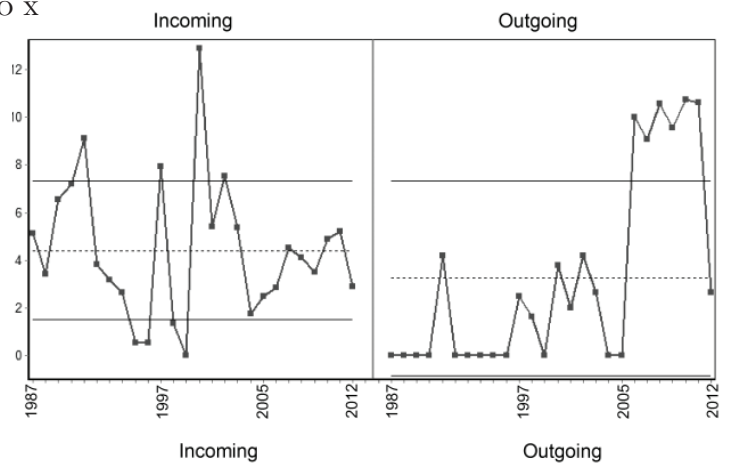

c)

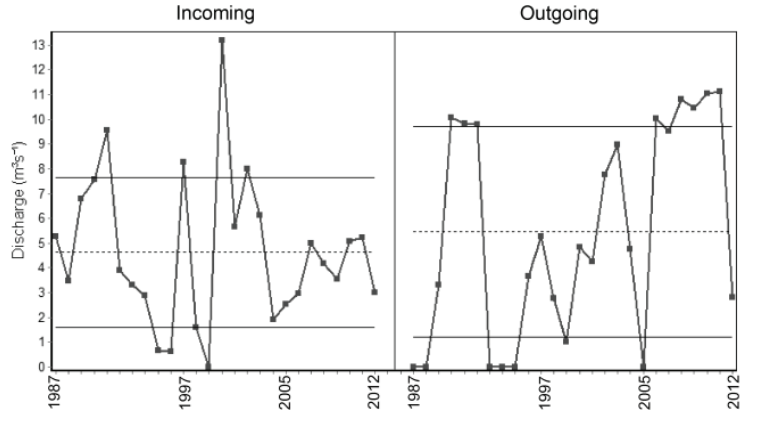

d)

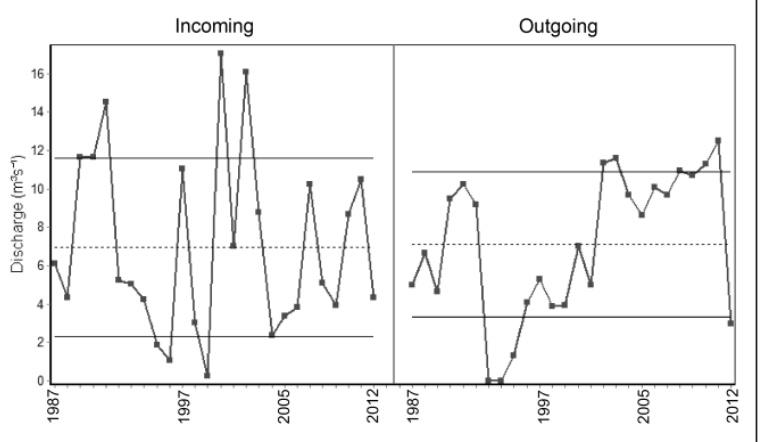

Figure 4 - Incoming and outgoing annual minimum discharge between 1987 and 2012: a) 1-day, b) 3-day, c) 7-day, d) 30-day 
consecutive years (1993 and 1994) with outgoing null discharges. The almost total lack of synchronism between the incoming and outgoing discharges throughout the years is worth noting.

\section{Low-flow pulses}

The number of low-flow pulses $\left(<11 \mathrm{~m}^{3} \mathrm{~s}^{-1}\right)$ recorded upstream from the dam had a mean value of 4.7 , whereas the low-flow pulses were equal to 46.6, 13.3 and 14.4 during the periods 1987-1996, 1997-2004 and 2005-2012, respectively (Figure 5). In relation to low flow pulse duration, while there was an annual variation upstream with a mean value of 20 days (but up to 57 days annually), the pulse duration downstream was significantly reduced, except for the year 2012.

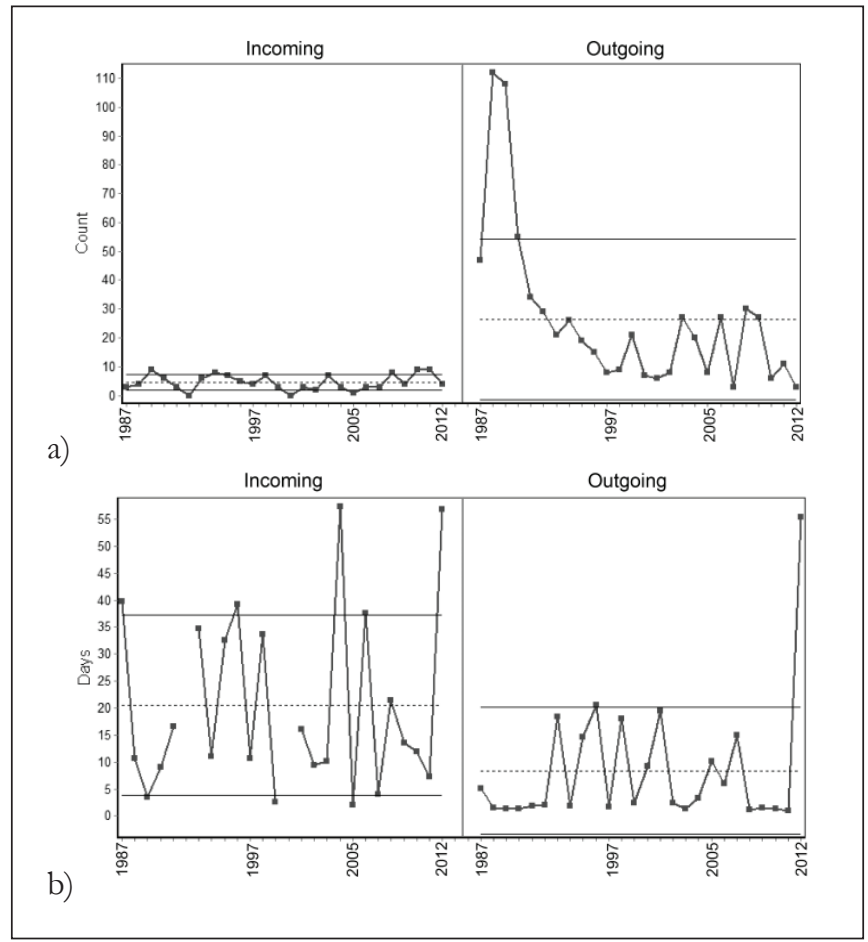

Figure 5 - Pulses of low discharge incoming and outgoing of the dam between 1987 and 2012: a) number of pulses; b) duration

\section{Flow duration curve (FDC)}

The FDCs of the incoming and outgoing discharges show differences in all discharge spectra. Figures $6 \mathrm{a}$ and $6 \mathrm{~b}$ show that between 1987 and 2004, there was a reduction of the outgoing discharge in all (1987-1996) or most (1997-2004) of the flow duration classes. Floodgate closure between 1987 and 1996 also caused null discharges to increase from almost $0 \%$ in the incoming discharge to $30 \%$ in the outgoing discharge. Changes in the operational guidelines in 1997 supposedly eradicated null discharges, but the flood gates were known to be opened for only 4 to 5 hours daily, when the released discharge was between $50 \mathrm{~m}^{3} \mathrm{~s}^{-1}$ e $60 \mathrm{~m}^{3} \mathrm{~s}^{-1}$. The maintenance of a constant flow (16.5 $\mathrm{m}^{3} \mathrm{~s}^{-1}$ to $\left.11 \mathrm{~m}^{3} \mathrm{~s}^{-1}\right)$ between the 25 th and 75 th percentiles, the minimum stream flow, is also notable.

Figure 6c clearly shows the changes in the outgoing discharge after the power plant went into operation. The step-like fashion of the outgoing-discharge curve is ascribed to the three modes of operation of the power plant. The smallest discharge value $\left(\sim 11 \mathrm{~m}^{3} \mathrm{~s}^{-1}\right)$ is associated with the discharge minimum ( $>40 \%$ of the time), with 1 turbine operating a few hours per day (peak demand). The second operational stage (20\% of the time) is associated with the operation of one turbine (discharges between $40 \mathrm{~m}^{3} \mathrm{~s}^{-1}$ and $78 \mathrm{~m}^{3} \mathrm{~s}^{-1}$ ). The highest discharge values occur with the operation of two turbines, with a maximum of $156 \mathrm{~m}^{3} \mathrm{~s}^{-1}$ (5\% of the time) or greater (3\% of the time) when aided by the floodgates.

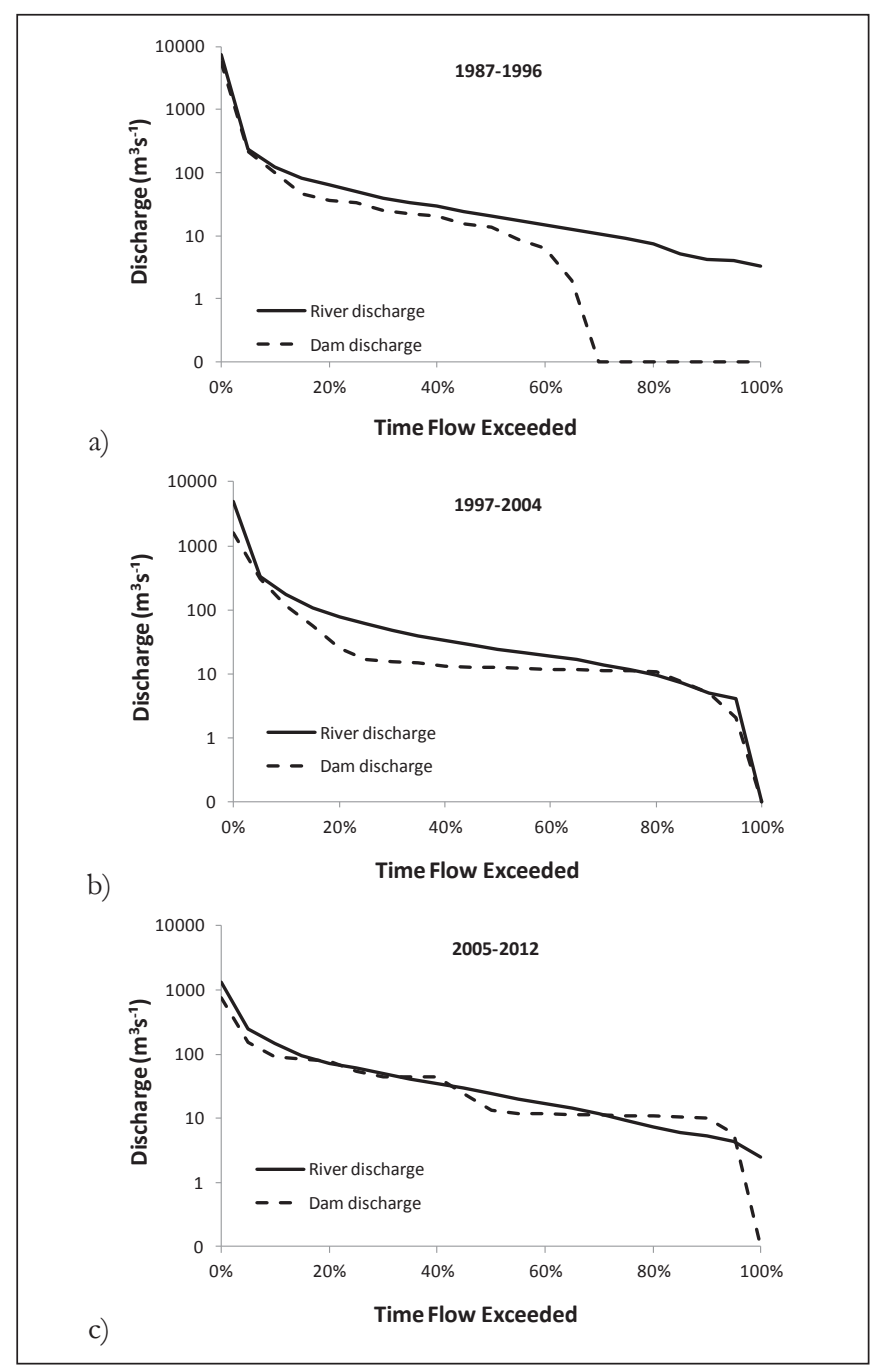

Figure 6 - Flow duration curves - incoming flow (River discharge) and outgoing flow (Dam discharge) of the Pedra do Cavalo Dam during: a) 1987 - 1996; b) 1997 - 2004; c) 2005 - 2012

The ecochange analysis indicates an overall discharge loss (ecodeficit) in the system (Figure 7a). Although ecosurpluses exist in the dry and wet seasons, they are significantly smaller than the ecodeficits (Figure 7b). The minimization of null discharges between 1997 and 2004 resulted in larger deficits in FDC ranging from $15 \%$ to $70 \%$ (Figure 6). These deficits practically doubled the annual and dry season ecochange, whereas the wet season deficit was slightly reduced. With the beginning of hydropower generation, the annual and dry season ecochange was reduced to 
approximately $30 \mathrm{~m}^{3} \mathrm{~s}^{-1}$. Once again, the wet season ecochange moved in the opposite direction, equaling the annual change.

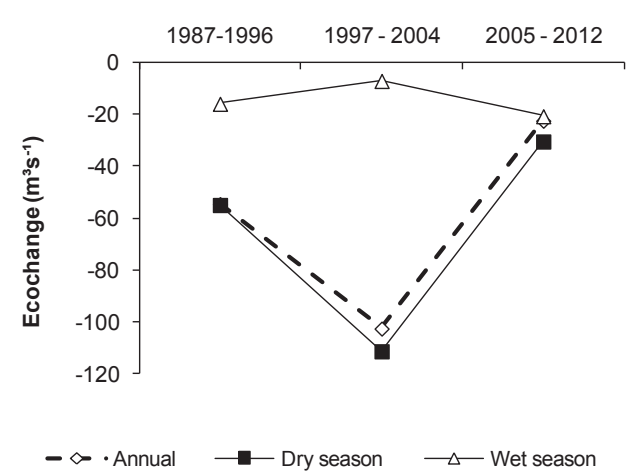

a)

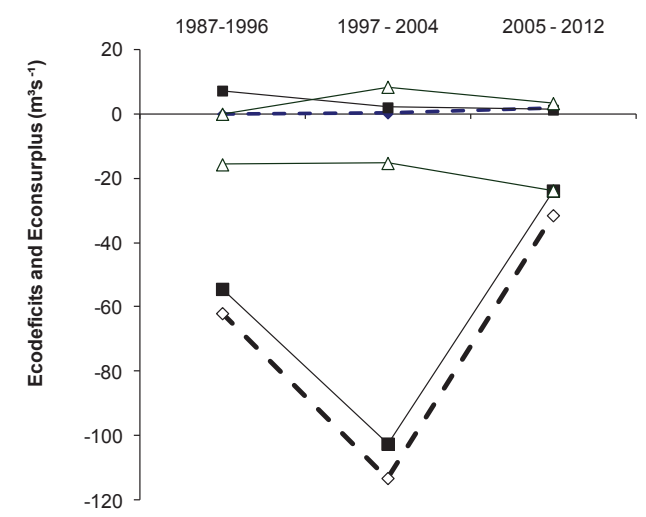

b)

Figure 7 - Progression of the ecodeficits, ecosurplus and ecochanges in the 3 different periods of dam operation, both annually and for the wet (Nov-Feb) and dry (Mar-Oct) seasons

\section{Seasonal Curve}

The distribution of month-mean values shows that important changes occurred after the annual flood period (December to February) (Figure 8). There was a generalized reduction of the mean flow. These changes are more clearly observed in a detailed observation of the month of June (figure 9), when the dam retains most of the river discharge. Between

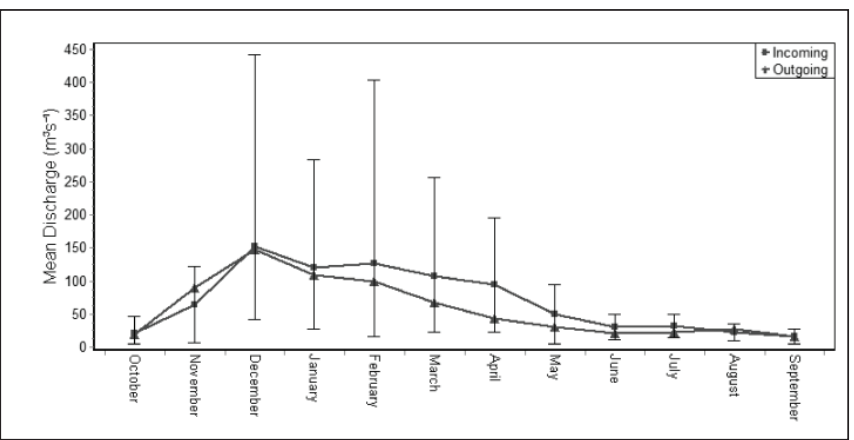

Figure 8 - Changes in the seasonal distribution of the monthly mean incoming and outgoing values (vertical bars indicate the RVA limits)
Oct/1986 and Sep/2004, small mean discharges occurred most of the time, but after the power plant went into operation, there were cases when the outgoing discharges were in fact higher than the incoming discharges.

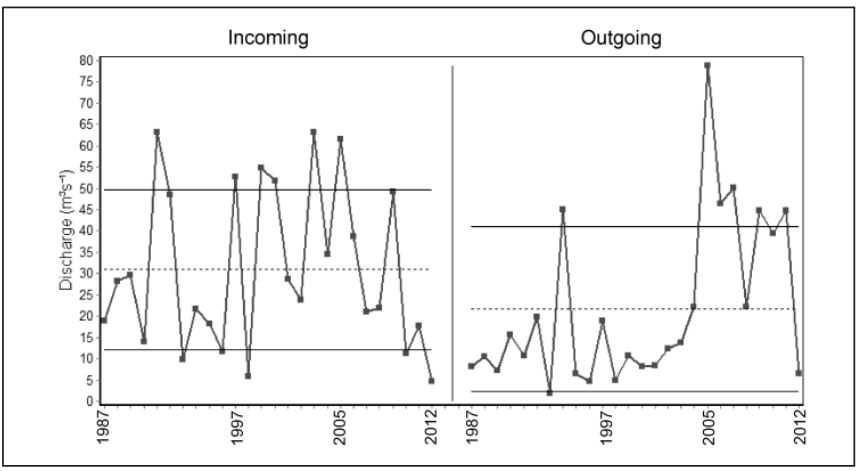

Figure 9 - Monthly mean incoming and outgoing discharges for the month of June

\section{Other impacts}

Two parameters associated with the hydrogram shape showed noteworthy results: the rates of ascension and recession of the hydrogram (Figure 10a and 10b) and the number of reversions (Figure 10c). From 1997 to 2004, the ascension

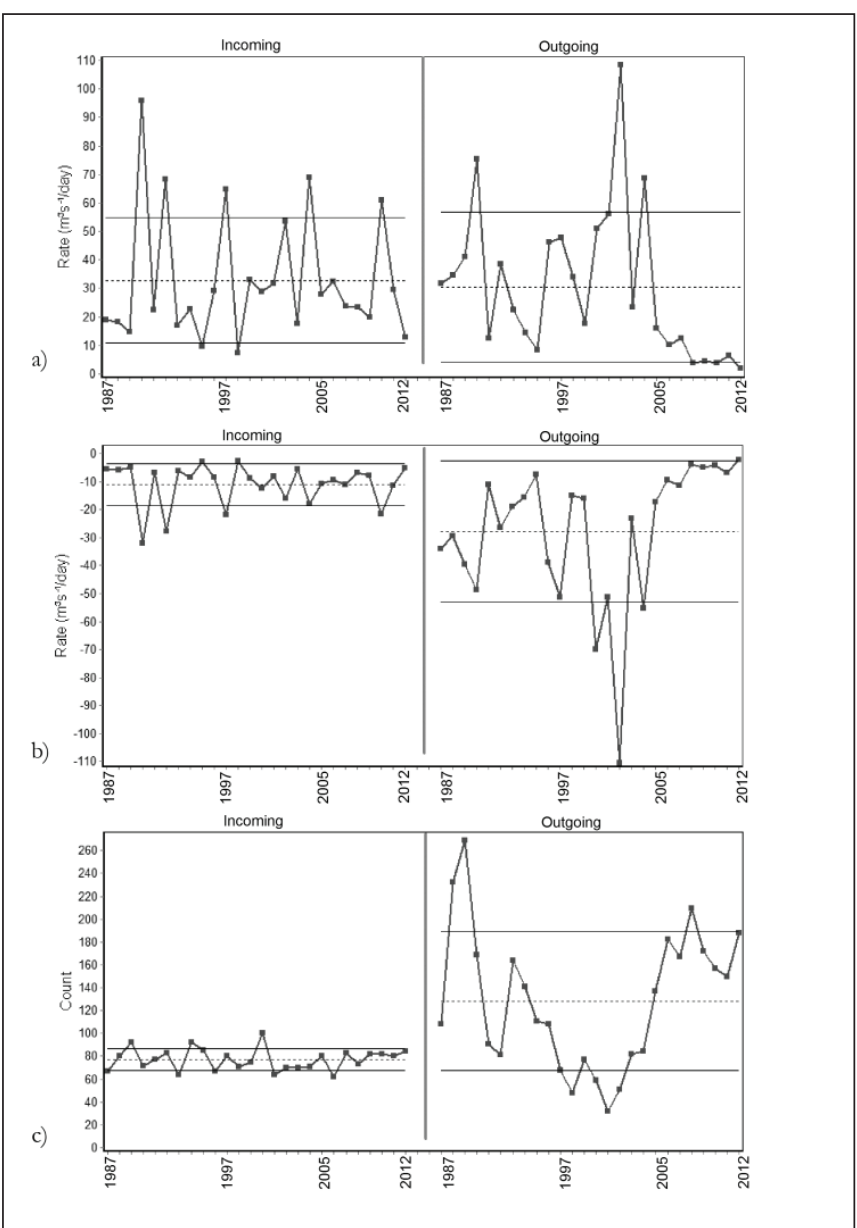

Figure 10 - Hydrogram shape parameters for the incoming and outgoing flow between 1987 and 2012: a) ascension rate, b) recession rate, and c) number of reversions 
(recession) rates of the hydrogram were altered, with higher (smaller) values associated with the outgoing flow. After 2005, with the power plant operation, the ascension and recession rates became smaller in the outgoing flow $\left( \pm 7.5 \mathrm{~m}^{3} \mathrm{~s}^{-1} /\right.$ day $)$ (Figure 10), indicating that the frequency or volume discharged through the floodgates was diminished due to the hydroelectricity demand.Nevertheless, the average recession rate increased from $-11 \mathrm{~m}^{3} \mathrm{~s}^{-1} /$ day to $-28 \mathrm{~m}^{3} \mathrm{~s}^{-1} /$ day.

The difference between the number of reversions of the hydrogram in the incoming and outgoing flow was also striking, with much less reversion occurring in the incoming flow (Figure 10c). The number of reversions upstream oscillated between 51 and 100 per hydrological year (mean of 77), whereas downstream, the reversions varied between 30 and 269 per year, with a mean of 128 . Once again, the largest number of reversions took place between 1987 and 1996.

\section{DHRAM Method}

The lower Paraguaçu River course is classified as a highly impacted river in accordance with the DHRAM method, which is based on changes of the mean and standard deviation of IHA groups (Table 4). Due to the existence of null discharges resulting from floodgate closure and hourly discharge oscillations, this classification of a severely impacted river is justified.

Table 4 - Changes of mean and CV values of IHA groups

\begin{tabular}{|c|c|c|c|c|c|}
\hline \multirow{2}{*}{$\begin{array}{c}\text { IHA Score } \\
\text { Group }\end{array}$} & \multicolumn{2}{|c|}{ Meanchanges } & \multicolumn{2}{|c|}{ Impact points } & \multirow[t]{2}{*}{ TOTAL } \\
\hline & Mean & CV & Mean & $C V$ & \\
\hline $\begin{array}{l}\text { 1. Monthly } \\
\text { Discharges }\end{array}$ & $24.6 \%$ & $47 \%$ & 1 & 1 & 2 \\
\hline $\begin{array}{l}\text { 2. Magnitude and } \\
\text { duration }\end{array}$ & $1730 \%$ & $45 \%$ & 3 & 0 & 3 \\
\hline $\begin{array}{l}\text { 3. Timing of } \\
\text { annual extreme } \\
\text { discharge }\end{array}$ & $11 \%$ & $25 \%$ & 1 & 0 & 1 \\
\hline $\begin{array}{l}\text { 4. Frequency and } \\
\text { duration of } \\
\text { high/low flow } \\
\text { pulses }\end{array}$ & $140 \%$ & $53 \%$ & 3 & 1 & 4 \\
\hline $\begin{array}{l}\text { 5. Rate/frequency } \\
\text { of hydrographic } \\
\text { change }\end{array}$ & $75 \%$ & $116.5 \%$ & 1 & 3 & 4 \\
\hline & \multicolumn{4}{|c|}{ Total points } & 14 \\
\hline & \multicolumn{4}{|c|}{ Interim classification } & 4 \\
\hline & \multicolumn{4}{|c|}{ Flow cessation } & $\overline{1}$ \\
\hline & \multicolumn{4}{|c|}{$\begin{array}{l}\text { Significant sub-daily } \\
\text { oscillation }\end{array}$} & 1 \\
\hline & \multicolumn{4}{|c|}{ Final classification } & 5 \\
\hline
\end{tabular}

\section{DISCUSSION}

The hydrologic changes identified by the flow duration curve and ascribed to the PCD do not follow the traditional model of flow regulation described by Magilligan and Nislow (2005), where the magnitude of the minimum discharges is increased. The dam shrank the downstream flow in all classes of flow duration due to the low frequency of floodgate operation, especially between 1987 and 1996, when a large number of null discharge events occurred. During 1997 to 2004, despite the similarities between the duration of the incoming and outgoing discharge frequencies higher than $70 \%$, the flows with frequencies from $25 \%$ to $70 \%$ remained restricted between $16.5 \mathrm{~m}^{3} \mathrm{~s}^{-1}$ and $11 \mathrm{~m}^{3} \mathrm{~s}^{-1}$. This flow was still lower than the incoming flow. Only after 2005 did the minimum outgoing discharges become larger than the incoming discharges.

The introduction of higher discharges with power generation (2005-2012) altered the monotony of the FDC from the previous period (1997-2004) (Figure 6) and reduced the ecochange (Figure 7). However, power generation brought about other types of impacts, such as changes in the hydrogram ascension and recession rates, an increasing number of reversions (Figure 10) and, in this case, the release of discharges far superior to the discharges occurring naturally in the winter time (Figure 9).

Also at odds with the expected response of a regulated river flow was the reduction of the monthly mean discharges throughout the low-flow season, i.e., when annual floods are less frequent (between 50\% and 76\% from March to July). This reduction was caused by the management strategy adopted by the Water Agency, which aimed at maintaining the highest possible water level. Higher than necessary water levels forced voluminous discharges prior to the wet season to prevent flooding downstream. As a consequence, the rates of ascension and recession of the hydrogram downstream were altered, as well as the timing of the hydrogram. These variables showed the highest impact in the IHA score.

This strategy was employed until 2005, when hydroelectricity generation commenced. Under this new scenario, low outgoing flow discharges became higher, in agreement with the expected response of a river regulated by hydroelectricity projects, as reported by Meyer et al. (2003) in the Savannah River (North Carolina, USA) and by Magilligan and Nislow (2005) for several other rivers in the United States.

The lack of a water releasing mechanism through the base of the dam has imposed an operation strategy that has generated flow pulses and a large number of reversions. Similarly to what occurred in the Roanoke River (USA) (Richter et al 1996), low flow pulses were reduced in duration but increased in frequency.

The use of upstream and downstream gauged discharges, rather than a comparison with a previous time period when the river was not regulated, was justified because of the difficulty of identifying a similar length of time with a climatic condition when the dam was in operation. Historic discharge data from the Paraguaçu River (GENZ, 2006) show the existence of decadal cycles with amplitudes larger than $30 \mathrm{~m}^{3} \mathrm{~s}^{-1}$. Similar phenomena have also been reported for other rivers in South America, including those in NE Brazil (ROBERTSON; MECHOSO, 1998; GENZ; TANAJURA, 2012). Therefore, caution must be taken in matching the regulated river discharge series with an unregulated series (similar positions within long term cycles); otherwise, impact indexes such as IHAs cannot be validated. The damming of the Paraguaçu River coincided with a drier period, which augmented the negative impacts of the dam. The mean annual river discharge during the period of dam operation was $47 \%$ lower than the pre-damming period 
Genz e Lessa: Twenty-six years of uneven changes in low flows due to different uses and operation of a large dam in a semiarid river

(1947 to 1986). Only in 7 out of the 26 years of the history of the dam has the annual Paraguaçu River discharge been higher than the long term average flow. Although natural changes in precipitation were the main driver for lower river discharges, the construction of two dams in the upper river course (109 million $\mathrm{m}^{3}$ in 1999; 111 million $\mathrm{m}^{3}$ in 2007) also affected the river flow incoming to the PCD reservoir.

The lower Paraguaçu River course is an important estuarine section of Todos os Santos Bay, and changes in the river flow have strong impacts on its circulation and thermohaline characteristics. Such impacts have had ecological consequences that are not yet well understood. The salinity field in the estuary has been modeled, taking the actual dam operation mode (hydroelectric power generation) into account (GENZ et al., 2008). To preserve the salinity structure (and ecological zonation) that has been established since the inauguration of the dam, the maximum turbine discharges should not be more than $66 \mathrm{~m}^{3} \mathrm{~s}^{-1}$.

\section{CONCLUSIONS}

The three different operational guidelines adopted for the PCD had a strong impact on the more frequent and minimum discharges released by the dam. Daily-average null discharges through the gates were common in the first 10 years of dam operation. The adoption of a minimum daily-average discharge after 1997 greatly reduced the frequency of null discharges but dramatically reduced seasonal variations. Hydropower generation after 2005 once again altered the characteristics of the smallest discharges, initiating the release of relatively high flow rates at times of the year with low natural discharges. The hydrological impacts calculated using the DHRAM method were classified as severe, and the ecochanges have been characterized by deficits throughout the life history of the dam.

The Paraguaçu River discharges have undergone large interannual variation, and the alternative use of the incoming river discharge and the outgoing dam discharge in the IHA method avoided climate cycle effects on the results of hydrological change. These cycles can cause discharge oscillations with amplitudes $>30 \mathrm{~m}^{3} \mathrm{~s}^{-1}$, or up to $40 \%$ of the annual mean discharge. The negative effects of the dam on the lower river course were enhanced by a relative drought condition that has prevailed since the dam was built.

Although the dam was primarily built to control flooding of downstream towns, the adopted operational guidelines suggest that maintaining high water levels in the reservoir to guarantee urban water supply has been a priority. There has been little concern for the environmental demands downstream of the dam, where the freshwater flow controls the extent of salt intrusion. The initiation of hydropower generation and the release of discharges higher than river discharges towards the reservoir might be causing important changes to the estuarine dynamics.

Once models that simulate reservoirs with daily resolution are in common use, performing an evaluation of hydrological changes in the project phase is highly recommended. Such an assessment would indicate whether there is a need to revise reservoir dimensions and create plans to prevent, minimize or compensate for the potential impacts of new dams.

\section{ACKNOWLEDGMENTS}

Fernando Genz thanks Fundação de Apoio a Pesquisa do Estado da Bahia (FAPESB) and Conselho Nacional de Pesquisa e Desenvolvimento (CNPq). Guilherme Camargo Lessa was supported by a CNPq research grant.

\section{REFERENCES}

AMORIM, J. L. R. Flood'scontrolat Pedra do Cavalo Dam. In: BERGA et al (eds). Dams and Reservoirs, Societies and Environment in 21st century. London: Taylor \& Francis Group, 2006.

ARTHINGTON, A. H.; BUNN, S. E.; POFF, N. L.; NAIMAN, R. $\mathrm{J}$. The challenge of providing environmental flow rules to sustain river ecosystems. Ecological Applications, v. 16, n. 4, p. 1311-1318, 2006.

BLACK, A.R.; ROWAN, J.S.; DUCK, R.W.; BRAGG, O.M.; CLELLAND, B.E. DHRAM: a method for classifying river flow regime alterations for the EC Water Framework Directive. Aquatic Conserv: Mar. Freshw. Ecosyst, v. 15, p. 427-446, 2005.

BRANDT, S. A. Classification of geomorphological effects downstream of dams. Catena, v. 40, p. 375-401, 2000

BRAZILIAN Committee on Large Dams. Highlights of Brazilian Dam Engineering, 2000. 75p.

CIRANO, M.; LESSA, G. C. Oceanographic characteristics of Baía de Todos os Santos, Brazil. Revista Brasileira de Geofísica, v. 25, p. 363387, 2007.

COLLIER, M.; WEBB, R.; SCHMIDT, J. C. Dams and River: A Primer on the downstream Effects of Dams. United State Geological Survey. Circular 1126, 2000. 94 p.

FINER, M.;JENKINS, C.N. Proliferation of Hydroelectric Dams in the Andean Amazon and Implications for Andes-Amazon Connectivity. PLOS ONE, v. 7, n. 4, e35126, 2012.

GAO, Y.; VOGEL, R.M.; KROLL, C.H.; POFF, N.L.; OLDEN J.D. Development of representative indicators of hydrologic alteration. Journal of Hydrology, v. 374, p.136-147, 2009.

GENZ, F. Avaliação dos Efeitos da Barragem Pedra do Cavalo sobre a Circulação Estuarina do Rio Paraguaçu e Baía de Iguape. 2006. 245f. PhD (Thesis) - Universidade Federal da Bahia, 2006.

GENZ, F.; LESSA, G. C.; CIRANO, M. Vazão mínima para estuários: um estudo de caso no Rio Paraguaçu/BA. Revista Brasileira de Recursos Hídricos, v. 13, p.73-82, 2008. 
GENZ, F.; LUZ, L. D. Distinguishing the effects of climate on discharge in a tropical river highly impacted by large dams. Hydrological Sciences Journal, v. 57, n. 5, p. 1020-1034, 2012.

GENZ, F; TANAJURA, C.A.S. Trends and variability of climate and river flow in the region of Costa das Baleias, Brazil. Water Science and Technology, p. 47-54, 2012.

GROPPO, J. D.; STENICO, A. C.; SALEMI, L.F.; BEDUSCHI, C.E.; TREVISAN, R. Análise do Efeito da Operação das Barragens do Sistema Cantareira no Regime Hidrológico do Rio Piracicaba. Revista Brasileira de Recursos Hídricos, v. 14, n. 1, p. 41-51, 2009.

KIESLING, R. L. Apphying Indicators of Hydrologic Alteration to Texas Streams - Overview of Methods with Examples from the Trinity River Basin. U.S. Department of the Interior. U.S. Geological Survey. USGS Fact Sheet 128-03, 2003.

LIAN, Y.; YOU, J.; SPARKS, R.; DEMISSIE, M. Impact of Human Activities to Hydrologic Alterations on the Illinois River. Journal of Hydrologic Engineering, v. 17, n. 4, p. 537-546, 2012.

LIMA, G. P. M.; LESSA, G. C.; FRANKLIN, T. S. Avaliação dos impactos da barragem de Santa Helena no trecho estuarino do rio Jacuípe, litoral norte da Bahia - Brasil. Quaternary and Environmental Geosciences, v. 2, n. 1, p.40-54, 2010.

LUZ, L.D.; GENZ, F. 2010. Environmental flows as one of the steps for attaining a more sustainable management for São Francisco River, Brazil. In: MORA ALISEDA, J; CONDESSO, F.; SÃO PEDRO, B. (Org.). Políticas Territoriales Y Tendencias en la Administración Pública del Agna. Lisboa, Portugal: ISCSP / Universidade Técnica de Lisboa, v. II, 2010. p. 104-125.

MAINGI, J. K.; MARSH, J.K. Quantifying hydrologic impacts following dam construction along the Tana River, Kenya. Journal of Arid Environments, v. 50, p. 53-79, 2002.

MAGILLIGAN, F.j.; NISLOW, K.H. Changes in hydrologic regime by dams. Geomorphology, v.71, p. 61-78, 2005.

MANYARI, W. V. Impactos Ambientais a jusante de hidrelétricas: o caso da usina de Tucuruí, PA. 2007. PhD (Thesis) - Universidade Federal do Rio de Janeiro, COPPE. Rio de Janeiro/RJ, 2007.

MATHEWS, R.; RICHTER, B.D. Application of the Indicators of Hydrologic Alteration Software in Environmental Flow Setting. Journal of the American Water Resources Association (JAWRA), v. 43, n. 6, p.14001413, 2007. DOI: 10.1111/j.1752-1688.2007.00099.x

MEYER, J.; ALBER, M.; DUNCAN, W.; FREEMAN, M.; HALE, C.; JACKSON, R.; JENNINGS, C.; PALTA, M.; RICHARDSON, E.; SHARITZ, R.; SHELDON, J.; WEYERS, R. Summary Report Supporting the Development of Ecosystem flow Recommendations for the Savannah River below Thurmond Dam. Summary Report 6/03, 2003. 150 p.
MOBLEY, J:; CULVER, T.; BURGHOLZER, R. Environmental Flow Components for Measuring Hydrologic Model Fit during Low Flow Events. Journal of Hydrologic Engineering, v.17, n.12, p.1325-1332, 2012.

NILSSON, C.; REIDY, C.A.; DYNESIUS, M.; REVENGA, C. Fragmentation and flow regulation of the world's large river systems. Science, v.308, p.405-408, 2005.

OLDEN, J. D.; POFF, N. L. Redundancy and the choice of hydrologic indices for characterizing streamflow regimes. River Research and Applications, v. 19, p. 101-121, 2003.

PEKÁROVÁ, P.; MIKLÁNEK, P.; PEKÁR, J. 2003. Spatial and temporal runoff oscillation analysis of the main rivers of the world during the 19th-20th centuries. Journal of Hydrology, v. 274, p. 62-79, 2003.

REVENGA, C.; BRUNNER, J.; HENNINGER, N.; KASSEM, K.; PAYNE, R. Pilot Analysis of Freshwater Ecosystems: Freshwater Systems. World Resources Institute, Washington, DC., USA, 2000. 83p.

RICHTER, B. D.; BAUMGARTNER, J. V.; POWELL, J; BRAUN, D. P. A Method for Assessing Hydrologic Alteration within Ecosystems. Conservation Biology, v. 10, n. 4, p.1163-1174, 1996.

RICHTER, B. D.; BAUMGARTNER, J. V.; WIGINGTON, R.; BRAUN, D. P. 1997. How much water does a river need? Freshwater Biology, v. 37, p. 231-249, 1997.

ROCHA, P.C. Indicadores de Alteração Hidrológica no Alto Rio Paraná: Intervenções Humanas e Implicações na Dinâmica do Ambiente Fluvial. Sociedade \& Natureza, v. 22, n. 1, p. 191-211, 2010.

ROSENBERG, D. M.; MCCULLY, P.; PRINGLE, C.M. Globalscale environmental effects of hydrologic alterations. BioScience, v. 50, p. 746-823, 2000.

SOUZA, C.F. Vazões ambientais em hidrelétricas: Belo Monte e Manso. 2009. Tese (Doutorado) - Instituto de Pesquisas Hidráulicas/ UFRGS, 2009.

STEVAUX, J.C. ; MARTINS, D.P. ; MEURER, M. Changes in a large regulated tropical river: The Paraná River downstream from the Porto Primavera Dam, Brazil. Geomorphology, v. 113, p. 230-238, 2009.

THARME, R. E. A Global Perspective on Environmental Flow Assessment: Emerging Trends in the Development and Application of Environmental Flow Methodologies for Rivers. River Research and Applications, v. 19, n. 5-6, p. 397-441, 2003.

VOGEL, R.M.; SIEBER, J.; ARCHFIELD, S.A.; SMITH, M.P.; APSE, C.D.; HUBER-LEE, A. Relations among storage, yield and instream flow. Water Resources Research, v. 43, 2007. doi:10.1029/2006WR005226.

WORLD COMMISSION ON DAMS. Dams and Development. Final Report, 2000. Acesso: www.dams.org/report/wcd_sumario.htm. 